\title{
THE USE OF PODCAST TO IMPROVE STUDENTS' SPEAKING COMPETENCY OF TENTH GRADE STUDENTS OF SMA NEGERI 1 AMLAPURA IN ACADEMIC YEAR 2015/2016
}

\author{
Oleh \\ A. S. Dianithi ${ }^{1}$, A. Mardjohan ${ }^{1}$, K. S. Piscayanti ${ }^{2}$ \\ Jurusan Pendidikan Bahasa Inggris, Universitas Pendidikan Ganesha \\ Singaraja, Indonesia \\ e-mail: i thiey97@yahoo.com ${ }^{1}$,asrilmardjohan@gmail.com¹, \\ sonia.piscaya@yahoo.com²
}

\begin{abstract}
Abstrak
Tujuan dari penelitian ini adalah peningkatan kemampuan berbicara siswa dalam Bahasa Inggris dengan penggunaan podcast dalam kegiatan belajar mengajar Bahasa Inggris.Penelitian ini dilaksanakan di SMA Negeri 1 Amlapura. Subjek dari penelitian ini adalah siswa kelas X MIA 1, dengan kemampuan siswa kelas X MIA 1 dalam berbicara dengan menggunakan Bahasa Inggris sebagai objek penelitian. Metode penelitian yang digunakan adalah penelitian tindakan kelas (PTK) yang dilakukan dalam dua siklus, masing-masing siklus meliputi langkah-langkah, perencanaan tindakan, pelaksanaan tindakan, observasi/evaluasi dan refleksi.Data yang diambil dalam penelitian ini adalah data kualitatif dan data kuantitatif.Data kualitatif diperoleh dari hasil kuisioner dan observasi.Sementara data kuntitatif didapat melalui hasil pre-test dan post-test yang diberikan kepada siswa. Hasil dari penelitian ini menunjukkan bahwa nilai rata-rata kemampuan berbicara siswa dengan menggunakan Bahasa inggris saat pre-test sebesar 60.43 , pada post-test 1 sebesar 72.46 , pada post-test 2 mencapai 79.78 dan jumlah siswa yang mencapai nilai ketuntasan dalam berbicara Bahasa Inggris naik menjadi $83.33 \%$. Oleh karena itu, dapat dikatakan bahwa implementasi podcastsebagai media pembelajarandalam kegiatan belajar mengajar Bahasa Inggris dapat meningkatkan kemampuan berbicara siswa.Selain itu, berdasarkan hasil kuesioner dan observasi selama kegiatan belajar mengajar berlangsung, dapat disimpulkan bahwa media pembelajaran ini juga dapat meningkatkan motivasi siswa untuk belajar Bahasa Inggris.
\end{abstract}

Kata Kunci: Berbicara, Kemampuan berbicara, TIK, Podcast

\begin{abstract}
The objective of this research was to improve students' English speaking competency by using podcast in teaching and learning. This research was conducted in SMA Negeri 1 Amlapura, as the subject of the research was the tenth grade students of SMA Negeri 1 Amlapura, i.e. X MIA 1 class. The object of research was English speaking competency of X MIA 1 students. The method used in this study was Classroom Action Research (CAR), conducted in two cycles. Each cycle consisted of the steps of planning, action, observation/evaluation and reflection. There were two kinds of data collected in this research namely qualitative and quantitative data. The qualitative data were obtained from the questionnaires and observation checklist. Meanwhile, the quantitative data were collected by conducting speaking pre-test and post-test. The result of study showed that the main score of the students' English speaking competency gained on the pre-test was 60.43 , on the post-test 1 was 72.46 and on post-test 2 was 79.78 and $83.33 \%$ of students could pass the standard
\end{abstract}


minimum score. It can be concluded that the English competency of the X MIA 1 students could be improved by using podcast in English teaching and learning. In addition, the result of the questionnaire and observation in the classroom showed that the students were more motivated to learn by using podcast.

Keywords: Speaking, Speaking Competency, ICT, Podcast

\section{INTRODUCTON}

Speaking became the most difficult skill to be mastered by the students of SMA Negeri 1 Amlapura.According to the students who had been interviewed, they could not speak English spontaneously while they were directly asked. The students need time to prepare what they were going to speak, first. It was caused by limitation of vocabulary that they had. They were also afraid of making mistakes in pronunciation and grammar. It made the students hesitate in speaking English for communication. It was also caused bythe technique that the teachers used,which made the students unable to practice speaking optimally. They almost never used English in their daily life except in the classroom while English teaching and learning was conducted. It means that the students only had a very short time to practice speaking.

Meanwhile, the new curriculum, the the 2013 curriculum which is used in SMA Negeri 1 Amlapura, expects the students to be able to use English in the real life for communication. What is happening in fact is still far from the expectation. The students are not able to speak English.

To solve these problems, a strategy is needed, which is able to attract the students to be involved in teaching and learning process, as well as giving them chances to have more time to practice speaking and helping them to enrich their knowledge about English vocabulary, sentence structure and intonation, so then they can speak spontaneously, fluently and correctly by using English.

The use of ICT, in this case podcast becomes the choice. Based on the preliminary observation made in SMA Negeri 1 Amlapura, this school has a language laboratory providing complete facilities that enable the students to use
ICT with good Internet connection. Besides, both the students and the teachers are get used to using ICT and Internet.

According to Amin (2011), ICT provides motivation to learn, because it can be used to provide challenging and authentic content that will engage the students in the learning process. It is more attractive and challenging to students to learn which increases their motivation to learn and listen to the teacher's guidance by putting ICT in the class. Podcast is one of the interesting media of ICTs that is chosen to solve the students' problems in speaking. According to Rossel-Aguilar (in Saputra 2014), the word podcast comes from two words, they are iPod and broadcast. Broadcast means getting information from television or radio (Sze, 2007).Podcast is audio (sometimes video) programs on web that are usually updated at regular time.Podcast contains of authentic material to teach speaking, because the students are directly given example how the native English is speaking which can be easily accessed and downloaded by computer or mobile phone, and then it can be listened by using mp3 player or video player.In accordance with the explanation above, this classroom action research was carried out to improve speaking competency of tenth grade students of SMA Negeri 1 Amlapura by using podcast.

Based on the research conducted by Paul Man in 2007, podcast can improve learners listening and speaking skills. The easiness of downloading podcast to MP3 players and iPods means that students can engage in plenty of listening and speaking practice while traveling. This research also found that the activities by using podcast is suitable for less confident learners, since it reduce the anxiety brought about by real-time interaction. In accordance with Sonali Rajpal and Anita Devi research, 
conducted in 2011, podcast as technology, revolutionizing learning process and shows podcast is useful for teacher and students in enhancing their knowledge in listening and speaking.

The result of this study is expected to give some significance to the teaching and learning of English, as following: (1) This research can enrich teachers' knowledge in improving students' speaking competency by the use of ICT, to conduct effective and efficient teaching, (2) It can help the students to learn English autonomously by making use of the ICT, so they can develop their communication skill, especially speaking skill, (3) This research is expected to be used as sources for the teachers who teach the same subject to be implemented in the classroom with the same problems,(4) It can be made as the sources and guidance for the researchers who are willing to conduct the same research or related research. Besides, it can motivate the next researchers to conduct the educational research.

\section{The Advantages of Using Podcast in Teaching}

In accordance with Bahadorfar (2014) Podcast allows students to use their teach-based environment system for educational purpose in which it enables to move away from the traditional face to face training without losing students and teacher relationship. In accordance with Paul Man (2006) there are some advantages in using podcast as the following: (1) it increases students' motivation, (2) it help to teach large class., (3) it can be used to teach students with mixed ability, (4) it focuses attention on accuracy.

\section{METHOD}

This research used classroom action-based research design, looking from the purpose of the study, to improve English speaking competency of students $X$ MIA 1 SMA Negeri 1 Amlapura, by using podcasting. The cycle process consisted of planning, action, observation, and reflection that took two cycles. The steps are explained as follows.

\section{Pre-Observation}

The preliminary observation conducted in $X$ MIA 1 Class of SMA Negeri 1 Amlapura, was aimed at knowing the factual condition of the problem face in the English teaching and learning, especially in speaking, specifically, the students competency in English speaking. The preobservation consisted of pre-test of the students' speaking competency which involved the aspects of cognitive, affective and psychomotor. Besides, there were pre-questionnaires distributed to the students.

\section{Planning}

In the planning, there were several stages included: (1) Preparing the materials and topics required for conducting the teaching and learning(2) Writing the teaching scenario in terms of instructional planning based on the use of podcasting. (3) Writing instrumentations required for the research such as questionnaire, observation sheet, and post achievement test. (4) Getting letter of recommendation and permission from the headmaster of School in which the research was conducted.(5) Getting access to school facilities to help the process of learning activities go smoothly.

\section{Action}

After all of the plans had been completely prepared, the action was conducted. The teaching and learning process in the classroom was managed based on the instructional planning of the use ofpodcasting, in which it involvedthe activities of observing, questioning, exploring, associating, and communicating. Here are steps of using podcast in teaching and learning (in case of teaching tenth grade of senior high school students): (1) Teacher makes the account and gives students username and password. (2) Teacher downloads some podcasts about self-experience (recount) then teacher introduces several podcasts to students in order to make students 
know what podcasts is and have clear picture about podcasts and the content. (3) Teacher asks students to observe the content of the podcasts, which are about recount text. (4) Teacher directs students to give questions based on the content of the podcasts. (5) Teacher asks students to be in pairs to discuss the questions rose. (6) Teacher leadsthe students to make a podcasts, at first they need to select the experience they will tell. (7) Then, students make the text of that recount text that will be recorded, because if we upload a podcasts we have to attach the podcasts with its transcription. (8) After the transcription done, students will practice to record audio or video. It can use camera, handy cam, and mobile phone, computer to record the audio or video. In this step, students will practice their pronunciation and accuracy in speaking. (9) After video finished, students will go to the account and upload the audio and the video with the transcription. (10) Teacher directs the students to download and listen to other students' audios or videos and provides comments (Paul Man, 2007). In this step, students will practice their listening skill as much as possible. This step can be done at school or home. Since the audios or videos uploaded on the internet, it is possible to have other audience on the internet will download the podcasts and give comments. This case provides students real audiences and real situation to practice their language.

\section{Observation/Evaluation}

The observation is a step of data collection to watch the effect of the action upon the goal. The effect of the action is monitored reflectively (Arikunto, 2010). During the action, the situation and the students' behavior as well as the progress of students were recorded on the of observation sheet that had been prepared previously. After conducting the action, the post test was conducted and the questionnaires were distributed to the students, to know their progress and opinions in and their feeling about the method of teaching implemented.

\section{Reflection}

Reflection refers to the analysis of the problem occurred in the action stage, to provide improvement as well as to prevent the same problem which might be occured in the next cycle. This phase explains about what, why and how the intervention contributes for the significant changing and improvement (Arikunto, 2010). In this stage, the result of observation were analyzed to know the improvement of Students' English competency. The cycle was stopped when the students in the classroom had achieved and passed the achievement indicators.

The standard minimum score determined as the achievement indicator is 72 . The cycle is stopped when $75 \%$ of students of X MIA 1 Class can pass that minimum standard score.

To collect data on this study, there are some instruments used, i.e.:

a. Questionnaire

There are two types of questionnaires that were used in this study. That is distributed to the students on the preliminary observation and by the end of each cycle. During the preliminary observation, the questionnaires were used to find the problem faced by the students in English speaking.

\section{b. Observation Checklist}

This instrument was used to collect the data about the students' performance of speaking and communication ability as well as their attitude during learning process. Especially, it was used to record the student's activities during teaching and learning process, whether the students enthusiastically followed the lesson and actively participated in the classroom during teaching and learning process as well as student's improvement in speaking.

\section{c. Pre-Test and Post-Test}

Pre and post- test instruments were used to collect data about students' speaking competency. The test consisted of several topics about recount text that students had to tell (speak about) related to the standard competency. The 
students' speech were recorded and analyzed.

\section{d. Assessment Rubric}

It is the assessment rubric of speaking which consisted of several criteria, such as fluency, intonation, pronunciation, confidence, and grammar. The rubric was used to assess the students speaking competency seen from the criteria made.

There are two data that were expected to be gained in this research, namely qualitative data, which was gathered from the result of observation sheets and the result of questionnaire that were distributed by the end of the cycle, and quantitative data that were obtained from the result of pre-test and post-test.

The results of questionnaire were obtained and calculated by following Likert Model. Whereas, in analyzing the quantitative data or numerical data, the researcher tried to get the average of students' speaking score per action within one cycle. It was used to know how well students' score as a whole on speaking. According to Sudjana (2002) it used the formula as follows:

$$
\bar{X}=\frac{\sum x}{n}
$$

Note:

\section{$\bar{X}:$ mean}

$x$ : individual score

$\mathrm{n}$ : number of students

Second, the researcher tried to get the class percentage which passed the minimum standard score considering English speaking competency gain score, 72 (seventy two) which was adapted from school agreement in the school. It used the formula (Sudijono, 2008):

Note:

$$
\mathrm{P}=\frac{F}{N} \times 100 \%
$$

$P$ : the class percentage

$F$ : total percentage score

$\mathrm{N}$ : number of students

Third, after getting mean score of students' score per action, the researcher identified whether or not the students' improvement score on speaking competency from pre-test to post-test 1 . According to Meltzer (2008), it can be obtained by using the formula
Note:

$$
\mathrm{P}=\frac{\mathrm{y} 1-\mathrm{y}}{y} \times 100 \%
$$

$\mathrm{P}$

percentage of students'
improvement

$y$ : pre-test result

y1 : post-test 1

Speaking competency from pre-test up to post-test score in cycle 1 and cycle 2 were analyzed by using formula:

$$
\begin{aligned}
& \mathrm{P}=\frac{\mathrm{y} 2-\mathrm{y}}{y} \times 100 \% \\
& \mathrm{Pote}: \\
& \quad \vdots \quad \text { percentage of students' } \\
& \text { improvement } \\
& \mathrm{y}: \text { pre-test result } \\
& \mathrm{y} 2 \quad \text { : post-test } 2
\end{aligned}
$$

\section{FINDINGS AND DISCUSSION}

\section{The Result of Pre-Questionnaire}

The pre-questionnaire was given to get the data about the problems faced in English speaking, by the students of $X$ MIA 1 SMA N Amlapura, and the factors that causedthe students had low competency in speaking, both internal factors and external factors. The internal factors are about the students themselves. Meanwhile the external factors can be related to the method implemented by the teacher and others factor occurred.

This pre-questionnaire consisted of 13 (thirteen) items which cover the statements divided in four categories. The first categoryis about students' opinion about speaking skill, which showed that $82.42 \%$ students stated that speaking is difficult skill to be mastered. However $84 \%$ of students considered that speaking is an important skill to be mastered and it is crucial to be able to communicate by using English.The second categoriesconsisted of the items of problem that students faced in speaking. $72.8 \%$ of students in X MIA 1 class said could not speak in English spontaneously. $68.8 \%$ of the students had problem to find the topic for speaking. $63.2 \%$ of the students had problem in pronouncing words. Meanwhile, problems in vocabulary mastery and grammar were faced by $60 \%$ of students in X MIA 1 class. The third 
categories consisted of the items about the factors that cause the problems, which includes internal and external factors. For the internal factors, showed $67.2 \%$ of the students said that they felt afraid and ashamed in making mistakes, especially in pronouncing words. The fourth categories included the solution that is needed by the students to solve the problem. The result showed, $82.4 \%$ of students stated that they needed a new and interesting strategy to be implemented in order to help them to improve their speaking competency.

\section{The Result of Pre Test}

Pre-test was conducted after doing the preliminary observation. It was aimed at knowing the students' English speaking competency before the classroom action research conducted. This pretest was done by giving students task to tell about their experiences which topics was determined by the lottery. The student's speech when they were telling their experiences were recorded by voice recorder and made as first quantitative data. The pre-test was conducted in 120 minutes. The result of pre-test is showed in table 1:

Table 1. The Result of Pre-Test of X MIA 1 Students

\begin{tabular}{|c|c|c|}
\hline $\begin{array}{c}\text { Pre- } \\
\text { Test } \\
\text { Scores }(X)\end{array}$ & n) & $(x)^{n}$ \\
\hline 33 & 1 & $3^{3}$ \\
\hline 37 & 2 & $4^{7}$ \\
\hline 43 & 1 & $3^{4}$ \\
\hline 47 & 2 & $4^{9}$ \\
\hline 50 & 4 & $00^{2}$ \\
\hline 53 & 3 & $59^{1}$ \\
\hline 60 & 1 & $0^{6}$ \\
\hline 63 & 3 & $89^{1}$ \\
\hline 67 & 4 & $68^{2}$ \\
\hline 70 & 2 & $40^{1}$ \\
\hline 73 & 1 & $3^{7}$ \\
\hline 77 & 4 & $08^{3}$ \\
\hline 83 & 1 & $3^{8}$ \\
\hline 90 & 1 & $0^{9}$ \\
\hline \multicolumn{2}{|c|}{ Total Score $\left(\sum_{\bar{x}}\right)$} & $814^{1}$ \\
\hline \multicolumn{2}{|c|}{ Mean $\left(\frac{\pi}{\underline{x}}\right)$} & $0.46^{6}$ \\
\hline
\end{tabular}

The percentage of students that had passed the minimum standard score of speaking, can be calculated as follows.

$$
\begin{aligned}
& P=F / N \times 100 \% \\
& P=7 / 30 \times 100 \%
\end{aligned}
$$




\section{$P=23.3 \%$}

Based on the pre-test result showed that the mean of pre-test score was 60.43 and there were only seven students or $23.3 \%$ of students that reached the minimum standard score. Meanwhile the other 23 students were below the criterion. It means that the English speaking competency of X MIA 1 students was still very low. After analyzing the result of preliminary study, it could be concluded that most of students of X MIA 1, SMA Negeri 1 Amlapura had problem in speaking, especially in pronunciation and confidence to speak. As well as they needed additional time to be able to practice speaking. They needed a new strategy that enables them to practice more and build up their confidence which can solve their problems in speaking.
The Result of Post-Test1 (Cycle I)

The post-test was conducted by asking the students to record their video about their experiences in the form of recount text. The videos were made as group project but everyone in the group had turn to speak. The videos were recorded and then discussed together in the classroom. After they were given comment and correction, the students had to make the revision of the videos.After the videos were revised, the students submitted the first revision of the videos to the teacher including the scripts. Then videos revised were assessed and the score were used as the post-test of first cycle. The result can be seen in table 2 .

Table 2. The Result of Post-Test 1 of X MIA 1 students

\begin{tabular}{|c|c|c|}
\hline $\begin{array}{c}\text { Pre- } \\
\text { Test } \\
\text { Scores }(\mathrm{X})\end{array}$ & n) & $(x)^{n}$ \\
\hline 47 & 1 & $7^{4}$ \\
\hline 53 & 2 & $06^{1}$ \\
\hline 57 & 2 & $14^{1}$ \\
\hline 63 & 3 & $89^{1}$ \\
\hline 67 & 2 & $34^{1}$ \\
\hline 70 & 3 & $10^{2}$ \\
\hline 73 & 1 & $3^{7}$ \\
\hline 77 & 6 & $62^{4}$ \\
\hline 80 & 3 & $40^{2}$ \\
\hline 83 & 4 & $32^{3}$ \\
\hline 87 & 2 & \\
\hline 93 & 1 & $3^{9}$ \\
\hline \multicolumn{2}{|c|}{ Total Score $\left(\sum_{\star}\right)$} & $174^{2}$ \\
\hline \multicolumn{2}{|c|}{ Mean $\left(\frac{\bar{x}}{x}\right)$} & $2.46^{7}$ \\
\hline
\end{tabular}

The percentage of students that had passed the minimum standard score of speaking, could be calculated as follows. 


$$
\begin{gathered}
P=F / N \times 100 \% \\
P=18 / 30 \times 100 \% \\
P=60 \%
\end{gathered}
$$

From the result of the post-test 1 , it could be seen that there were improvement of students' speaking competency on the pre-test. The students who could pass the minimum standard score on the post-test 1 also increased from the pre-test, in which $23.3 \%$ of the students could pass the minimum standard score on the pre-test, it became $60 \%$ on the post-test 1 . Meanwhile, the mean score of students' speaking competency on the pre-test was 60.43 . It improved on the post-test became 72.46. The percentage of improvement of pretest mean score was $19.87 \%$.

The improvement of mean score was derived by using formula as follows.

$$
\begin{gathered}
\mathrm{P}=(\mathrm{y} 2-\mathrm{y}) / \mathrm{y} \times 100 \% \\
\mathrm{P}=(72.46-60.43) / 60.43 \times 100 \% \\
\mathrm{P}=19.87 \%
\end{gathered}
$$

In this cycle, there were improvement of students' speaking competency. However the number of the students that could pass the standard minimum score were still below $75 \%$, as the target of the research. It means that the research had to be continued to the next cycle. Seeing from the students' participation in the classroom during learning and teaching activities that recorded by observation checklist, the students still felt unconfident to speak in the discussion season while they were asked to give their comment to the other groups' project, unless they were pointed out by the teacher. To make all of the students actively participated to speak in discussion season, the implementation of the strategy had to be revised. The researcher made a rule on discussion season to handle the silent situation. The rule was the students that gave comment previously had to choose the other friend to give next comment. So, everyone had turn and chance to speak in the discussion.Looking from the students' performance on their project, in this case telling theirexperiencein the form of recount text, it still needed some improvement especially inpronunciation. So, the teacher need to give example of pronouncing the words that was difficult but often used by the students.

\section{The Result of Post-Test 2 (Cycle 2)}

In this post-test the students told the story in front of the classroom then the teacher assessed their performance. This activities also recorded by using video camera. The score obtained from the

\begin{tabular}{|c|c|c|}
\hline $\begin{array}{c}\text { Pre- } \\
\text { Test } \\
\text { Scores }(X)\end{array}$ & n) & $(x)^{n}$ \\
\hline 67 & 4 & $68^{2}$ \\
\hline 70 & 1 & $0^{7}$ \\
\hline 73 & 5 & $65^{3}$ \\
\hline 77 & 3 & $31^{2}$ \\
\hline 80 & 3 & $40^{2}$ \\
\hline 83 & 4 & 3 \\
\hline
\end{tabular}
post-test2 conducted, where the students were recorded by using video camera while they conveyed other groups' story. The result can be seen in table 3 .

Table 3. The Result of Post-Test 2 of X MIA 1 students 


\begin{tabular}{|c|c|c|}
\hline & & 32 \\
\hline 87 & 7 & $09^{6}$ \\
\hline 90 & 1 & $0^{9}$ \\
\hline 93 & 1 & $3^{9}$ \\
\hline 97 & 1 & $7^{9}$ \\
\hline \multicolumn{2}{|c|}{ Total Score $\left(\sum_{\gtrsim}\right)$} & $395^{2}$ \\
\hline \multicolumn{2}{|c|}{ Mean $\left(\frac{\bar{x}}{x}\right)$} & $9.78^{7}$ \\
\hline
\end{tabular}

The percentage of students that had passed the minimum standard score of speaking, could be calculated as follows:

$$
\begin{gathered}
P=F / N \times 100 \% \\
P=25 / 30 \times 100 \% \\
P=83.33 \%
\end{gathered}
$$

The result of the study on cycle II, showed that there were 25 students or $83.33 \%$ of students in X MIA 1 class that could pass the standard minimum score. The score obtained on the post-test 2 showed that the mean score of students'
English speaking competency was 79.88. It means that the mean score improved from the post-test 1 mean score, 72.46 . The students that could pass the standard minimum score of English speaking competency also increased.

To know the percentage of the mean score improvement from post-test 1 to post-test 2, it can be counted by using the formula as follows.

$$
\begin{gathered}
P=(y 2-y) / y \times 100 \% \\
P=(79.78-72.46) / 72.46 \times 100 \% \\
P=10.13 \%
\end{gathered}
$$

From the action and the observation that had been conducted, it could be reflected that there were improvement of English speaking competency of students $X$ MIA 1 SMA Negeri 1 Amlapura. Besides their speaking ability improved, their confidence in speaking also increased. As well as they were also very interested and motivated to learn while teaching by using podcast was implemented. It was seen from the observation done, where the students were more active to speak during the teaching and learning process, both in discussion and telling recount text.

The improvement showed by the data obtained was $83.33 \%$ of students could pass the minimum standard score determined for English speaking competency, with the mean score achieved by the students was 79.88. It could be said that result of study had reached the success indicators, in which more than $75 \%$ of students could pass the standard minimum sore. It means that the research could be stopped.

The whole mean score improvements of English speaking competency of X MIA 1 students of SMA Negeri 1 Amlapura are pictured in Figure 1. 
Figure 1. The Improvements of English speaking competency of X MIA 1 students

The Improvements of English Speaking competency of $X$ MIA 1 Students

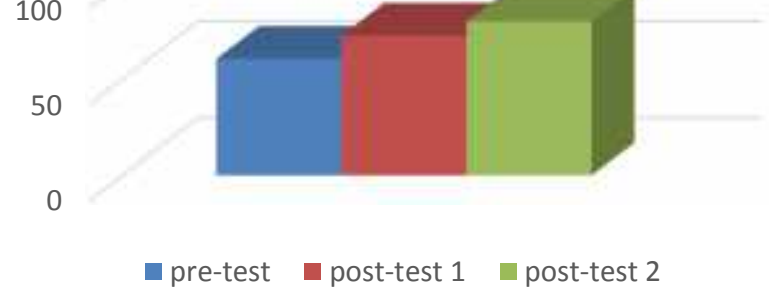




\section{The Result of Post-Questionnaire}

The distribution of questionnaires had purpose of knowing the students response toward the strategy implemented, whether the strategy was interesting and helpful for the students.

The post questionnaires distributed were consisted of 12 items which were classified into three categories. The first categories, covers the statements to know the students opinion about podcast as learning media. The result of questionnaires showed that $83.2 \%$ of students were motivated to learn when teaching and learning by using podcast was implemented. The second categoriesconsisted of the statements, used to get students opinion about the easiness of using podcast. $76.8 \%$ of students X MIA 1 Class agreed that podcast was easy to be accessed and used. The third categories, used to know how helpful podcast in improving their skill. The result showed that $71.2 \%$ students agreed that podcast could help them to involve in teaching and learning process, $76 \%$ students said that podcast gave more time to practice. Almost $70 \%$ of students stated that podcast helped them in learning vocabulary, pronunciation, grammar, intonation, even improve their confidence in speaking skill.

In conclusion, the findings of the study prove that podcast could improve English speaking competency of X MIA 1 students of SMA Negeri 1 Amlapura. It seemed from the mean score of English speaking competency of X MIA 1 students, inwhich it significantly improved on the pretest, post-test 1 and post-test 2. The mean score of pre-test was 60.43 , it improved $19.87 \%$ in the post-test 1 . The mean score obtained on the post-test 1 was 72.46. In the post-test 2, test that was given on the second cycle, the students' main score became 79.88, which improved $10.13 \%$ from the main score of the post-test 1 , the test that was given in the first cycle. In addition, the amount of improvement of students' speaking competency after learning by using podcast was $32.19 \%$. Through the observation done in every meeting during the research was conducted, showed that day by day the students more active participated in the teaching and learning activities. They were active to speak in the discussion and also feel enthusiastic in following the teaching and learning process. Besides, they did their project well and worked cooperatively with their friends.According the result of the questionnaires that had been distributed to the students, in order to know their response on the use of podcast, most of students felt interesting in learning by using podcast. The students were also motivated and helped by the implementation of podcast.

In addition, the result of this research had proven the theory from Stanley (2005), who said that podcast is a new technology which has huge potential in enhancing students' listening and speaking skill. It could be seen from the improvement of X MIA 1 students' mean score of English speaking competency on pre-test and posttest. It was also in line with the result of researches that had been conducted previously, i.e.: (1) The research conducted by Paul Man in 2007, entitled Developing Students' Listening and Speaking Skill through ELT Podcast, and (2)research entitled Podcast: Enhancing Listening and Speaking Skill, which conducted by Sonali Rajpal and Anita Devi in 2011.

\section{CONCLUSION AND SUGGESTION}

In conclusion, the use of podcast in teaching and learning process can improve speaking competency of X MIA 1 students of SMA Negeri 1 Amlapura. It can be seen from the achievement of the students that could pass the standard minimum score determined for English speaking skill 72, in which $83.33 \%$ of students could pass the standard minimum score after the use of podcast in English teaching and learning. The result of the study also showed that podcastmotivated them to improve their speaking competency and build up their self-confidence in speaking.

There are some suggestions that are offered to the English teachers and other researchers based on the research findings. (1)Podcast is an effective media to improve students speaking competency as long as the school provide facilities that support the use of podcast. (2) The use of 
podcast could help the children to make use the technology the used for learning which help the students learn easier and provide various interesting material that is able to defeat their boredom. (3) This strategy is suggested to the English teachers or other researchers who wants to conduct similar research in the school that provides facilities of ICT devices and internet access ability. (4) The researcher hopes that the result of this study can be made as an additional reference, there will be a further research with different discussion that can make revision within the development of using podcast in teaching.

\section{REFERENCES}

Arikunto, S. (2010). ProsedurPeelitian: SuatuPendekatanPraktek

(EdisiRevisi).Jakarta: RinekaCipta.

Basaran, S. \&Cabaroglu, N. (2014) International Journal of Language Academy: The Effect of Language Learning Podcasts on English SelfEffeciency. (2).2342-025 Provided at http://www.ijla.net/Makaleler/98914183 5.pdf.(accessed on 18 February 2015)

Bahadorfar, Maryam (2014). Acme International Journal of Multidisciplinary Research: Technology in Teaching Speaking Skill. (11).4Provided at http://www.ajimr.net/documents/2.4/240 2.pdf (accessed on 19 February 2015)

Diyyab, E. Aly., Abdel-Haq, Eman M.., \&Aly, M.A.(2013), Using Multimedia-Based Program for Developing Student Teachers' Speaking Fluency. Provided at

http://files.eric.ed.gov/fulltext/ED539987 .pdf (accessed on February 12, 2015)

Hasmi, F. \& Jain, S. (2013), Advantages of Podcast in English Language Classroom (1).2. Provided at http://mujournal.mewaruniverity.in/JIR2/ 23.pdf (accessed on January 14, 2015)

Kaffsah, Hamid Reza et all. (2010). International Journal of Instruction: $A$ Close Look into Role of ICT in
Education. (3).2. Provided at hhtp://files.eric.ed.gov/fulltext/ED52293 $\underline{\text { 6.pdf }}$

Man, Paul. (2007). Education Journal Winter 2006:Developing Students' Listening and Speaking Skills through ELT Podcast. (34).2. Provided at http://hkier.fed.chuk.edu.hk (accessed on 21 September 2014)

Meltzer, David E. (2008). The Relationship between Mathematics and Conceptual Learning Gains in Physics: A Possible Hidden Variable in Diagnostic Pretest Scores. Iowa: Department of Physics and Astronomy.

Oradee, Thayalak. (2012). International Journal of Social Science and Humanity: Developing Speaking Skill Using Three Communicative Activities (Discussion, Problem-Solving and Role Playing). (2).6.Provided at http://www.ijssh.org/papers/164-

A10036.pdf (accessed on February 15, 2015)

Patel, Ankit\&SchollarPhill (2015). Effectiveness of Podcast to Develop Language Skill of Post Graduate Students. ELT VIBES: International EJournal for Research in ELT. 1(1).2630. Provided at http://www.eltworld.in (accessed on 8 Feruary 2015)

Rajpal, Sonali. \&Devi, Anitha (2011). Language in India:Podcast: Enhancing Listening and Speaking Skills. Provided at

http://www.languageinindia.com/oct201 $1 /$ podcatfinal.pdf $\quad$ (accessed on 20January 2015)

Saputra, JuniBayu (2014). The International Journal of Humanities \& Social Studies: The Comparison of Listening Comprehension using Podcast with Audio-Visual at Different Listening Habit.Provided at http://www.theijhss.com/june2014/31.H S1406-029.pdf. (accessed on 18 February 2015) 
Stanley, G. (2005). Podcasting for ELT. Retrieved August 2, 2015, from http://www.teachingenglish.org.uk/think/ resources/podcast.shtml

Sudjana, (2002).Metoda Statistika. Bandung: PT. Trasito.

Sudjono, Anas. (1987). Pengantar Statistik Pendidikan. Jakarta:PT. RajavaGrafindo Persada

Sze, Paul. (2014).The Chines University of Hongkong:Developing Students'
Listening and Speaking Skills through ELT Podcasts. Provided at http://www3.fed.cuhk.ed.hk (accessed on 20 January 2015)

Ul-Amin, Syed Noor (2008).An Effective Use of ICT for Education and Learning by Drawing on Worldwide Knowledge, Research and Experience: ICT as a Change Agent for Education. Provided at

http://www.nyu.edu/classess/keefer/wao e/amins.pdf 